\title{
Degradation of methiocarb by monochloramine in water treatment: Kinetics and pathways
}

\author{
Zhimin Qiang ${ }^{a, *}$, Fang Tian ${ }^{a, b}$, Wenjun Liu ${ }^{b}$, Chao Liu ${ }^{a}$ \\ ${ }^{a}$ State Key Laboratory of Environmental Aquatic Chemistry, Research Center for Eco-Environmental Sciences, \\ Chinese Academy of Sciences, 18 Shuang-qing Road, Beijing 100085, China \\ ${ }^{\mathrm{b}}$ School of Environment, Tsinghua University, Beijing 100084, China
}

\section{A R T I C L E I N F O}

\section{Article history:}

Received 12 April 2013

Received in revised form

5 December 2013

Accepted 7 December 2013

Available online 18 December 2013

\section{Keywords:}

Methiocarb

Monochloramine

Degradation pathways

Kinetic modeling

Water treatment

\begin{abstract}
A B S T R A C T
The micropollution of drinking water sources with pesticides has become a global concern. This work investigated the degradation of methiocarb (MC), a most commonly-used carbamate pesticide, by monochloramine $\left(\mathrm{NH}_{2} \mathrm{Cl}\right)$ under simulated water treatment conditions. Results indicate that the reaction was of first-order in $\mathrm{MC}$ and varied orders in $\mathrm{NH}_{2} \mathrm{Cl}$ depending on water $\mathrm{pH}$. The observed rate constant of $\mathrm{MC}$ degradation decreased quickly with either a decrease in the molar ratio of chlorine to ammonia $\left(\mathrm{Cl}_{2}: \mathrm{N}\right)$ or an increase in water $\mathrm{pH}$. The apparent activation energy of the reaction was determined to be $34 \mathrm{~kJ} \mathrm{~mol}^{-1}$. The $\mathrm{MC}$ degradation pathways also exhibited a strong $\mathrm{pH}$ dependence: at $\mathrm{pH}$ $6.5, \mathrm{MC}$ was first oxidized by $\mathrm{NH}_{2} \mathrm{Cl}$ to methiocarb sulfoxide (MCX), and then hydrolyzed to methiocarb sulfoxide phenol (MCXP); while at pH 8.5, MCX, MCXP and methiocarb sulfone phenol (MCNP) were formed successively through either oxidation or hydrolysis reactions. Based on the identified byproducts and their concentrations evolution, the proposed pathways of $\mathrm{MC}$ degradation in the presence of $\mathrm{NH}_{2} \mathrm{Cl}$ were further validated through kinetic model simulations.
\end{abstract}

(c) 2013 Elsevier Ltd. All rights reserved.

\section{Introduction}

Methiocarb (mesurol, 3,5-dimethyl-4-(methylthio)phenyl methylcarbamate) (MC) is one of the most commonly-used carbamate pesticides worldwide (Keum et al., 2000; Gitahi et al., 2002; Altinok et al., 2006). It has been frequently detected in groundwater in various countries at concentrations ranging from 0.03 to $5.40 \mu \mathrm{g} \mathrm{L}^{-1}$ (Barcelo et al., 1996; Garcia de Llasera and Bernal-Gonzalez, 2001; Squillace et al., 2002; APVMA, 2005). Although the detected concentrations of MC in natural waters are generally low, it poses a serious health threat to aquatic life and human considering its high toxicity. The oral $\mathrm{LD}_{50}$ in rats for $\mathrm{MC}$ is in the range of $13-130 \mathrm{mg} \mathrm{kg}^{-1}$ body weight (bw) (Marrs, 1998). In aqueous environments, MC can be degraded to methiocarb sulfoxide (MCX) or lose its carbamate group to yield methiocarb phenol (MCP) (UNFAO and WHO, 1999; APVMA, 2005). The byproduct MCX is more toxic than MC, with an oral $\mathrm{LD}_{50}$ in rats of $6-43 \mathrm{mg} \mathrm{kg}^{-1}$ bw (Marrs, 1998). MCX is hence listed in the Priority List of Transformation Products in Great British Drinking Water Supplies as a result of comprehensive evaluations based on pesticide usage, toxicity, transformation products, mobility, and persistence (Sinclair et al., 2006).

\footnotetext{
* Corresponding author. Tel.: +8610 62849632; fax: +86 1062923541.

E-mail address: qiangz@rcees.ac.cn (Z. Qiang).
} 


\section{Nomenclature \\ MC Methiocarb \\ MCN Methiocarb sulfone \\ MCNP Methiocarb sulfone phenol \\ MCP Methiocarb phenol \\ MCX Methiocarb sulfoxide \\ MCXP Methiocarb sulfoxide phenol}

Monochloramine $\left(\mathrm{NH}_{2} \mathrm{Cl}\right)$ has been increasingly used as an alternative disinfectant to free chlorine or as a secondary disinfectant post chlorination because it is less reactive towards natural organic matter (NOM) and thus produces a lower level of regulated disinfection byproducts (DBPs) (Duirk et al., 2002; Greyshock and Vikesland, 2006). Extensive researches have been conducted on the formation of DBPs during water monochloramination (Choi and Valentine, 2002; Qi et al., 2004). Though $\mathrm{NH}_{2} \mathrm{Cl}$ has a low reactivity towards $\mathrm{NOM}$, it can still react with many chemical contaminants with reaction rates dependent on water $\mathrm{pH}$ and the molar ratio of chlorine to ammonia $\left(\mathrm{Cl}_{2}: \mathrm{N}\right)$ (Heasley et al., 2004; SandínEspaña et al., 2005; Chamberlain and Adams, 2006; Greyshock and Vikesland, 2006). In general, its reactivity towards a chemical contaminant increases as water $\mathrm{pH}$ decreases. It was also reported that the degradation of triclosan by $\mathrm{NH}_{2} \mathrm{Cl}$ slowed down as the $\mathrm{Cl}_{2}: \mathrm{N}$ ratio decreased (Greyshock and Vikesland, 2006).

Although water treatment processes can sometimes reduce the concentrations of many pesticides (Ormad et al., 2008), the formation of byproducts may increase the toxicity of treated water (Wu and Laird, 2003). Our previous study has found that the toxicity of MC solution increased after $\mathrm{ClO}_{2}$ treatment (Tian et al., 2010). However, to date, little is known about the kinetics and mechanism of MC degradation by $\mathrm{NH}_{2} \mathrm{Cl}$, particularly in terms of degradation byproducts. Therefore, the aim of this study was to determine the reaction kinetics, identify major degradation byproducts, and elucidate the pathways of $\mathrm{MC}$ degradation in the presence of $\mathrm{NH}_{2} \mathrm{Cl}$. The results would clarify the fate and behavior of $\mathrm{MC}$ during water disinfection with $\mathrm{NH}_{2} \mathrm{Cl}$, thus help ensure the drinking water safety.

\section{Materials and methods}

\subsection{Chemicals}

MC (98.5\%) was purchased from Dr. Ehrenstorfer $\mathrm{GmbH}$, and MCX (98.2\%), MCN (94.4\%) and N,O-bis(trimethylsilyl)-trifluoroacetamide (BSTFA) containing 1\% trimethylchlorosilane were from Sigma-Aldrich. Methanol, acetone, and acetonitrile of high performance liquid chromatography (HPLC) grade were obtained from Fisher Scientific, and methyl tert-butyl ether (MTBE, HPLC grade) was from Tedia. Other chemicals were of at least analytical grade and used without further purification.

The stock solutions of MC, MCX and MCN were prepared individually in methanol with a concentration of about
200-300 $\mathrm{mg} \mathrm{L}^{-1}$. The mixed calibration standards containing MC, MCX and MCN (0.25-10.0 $\mu \mathrm{M})$ were prepared from their stock solutions and $0.1 \mathrm{M} \mathrm{HCl}$ was added to prevent hydrolysis. The standard solutions of MCP, MCXP and MCNP were prepared respectively by hydrolyzing a desired volume of the stock solutions of MC, MCX and MCN with $1 \mathrm{~mL}$ of $2.0 \mathrm{M} \mathrm{NaOH}$ for about $1 \mathrm{~min}$, and then acidifying with $5 \mathrm{~mL}$ of $2.0 \mathrm{M} \mathrm{HCl}$. The completeness of hydrolysis was confirmed by liquid chromatography/photodiode array/mass spectrometry (LC/ PDA/MS, Alliance 2695 HPLC and ZQ4000 MSD, Waters) analysis. $\mathrm{NH}_{2} \mathrm{Cl}$ was freshly prepared by mixing $\mathrm{NaOCl}$ and $\mathrm{NH}_{4} \mathrm{Cl}$ solutions at a $\mathrm{Cl}_{2}: \mathrm{N}$ molar ratio of 0.8 at about $\mathrm{pH} 10$ except otherwise stated. $\mathrm{NH}_{4} \mathrm{Cl}$ was purposely applied in excess to achieve a $100 \%$ yield of $\mathrm{NH}_{2} \mathrm{Cl}$ and suppress the spontaneous decomposition of the formed $\mathrm{NH}_{2} \mathrm{Cl}$ as well (Qiang and Adams, 2004). All reaction solutions were prepared with ultrapure water produced by a Milli-Q system (Advantage A10, Millipore) and buffered with $10 \mathrm{mM}$ phosphate in the $\mathrm{pH}$ range of 6.1-8.9.

\subsection{Hydrolysis experiments}

The hydrolysis kinetics of MC, MCX and MCN was studied separately in $60 \mathrm{~mL}$ brown glass reactors to exclude potential light influence. The reaction solution of a target compound was freshly prepared by diluting its stock solution with ultrapure water containing $10 \mathrm{mM} \mathrm{KH}_{2} \mathrm{PO}_{4}$. The hydrolysis reaction was initiated by addition of a desired volume of $2.0 \mathrm{M} \mathrm{NaOH}$ solution and terminated by addition of $2.0 \mathrm{M} \mathrm{HCl}$ solution. Samples were withdrawn at pre-selected time intervals and analyzed for the residual MC concentrations with HPLC/PDA.

\subsection{Degradation experiments}

MC degradation by $\mathrm{NH}_{2} \mathrm{Cl}$ was studied under pseudo-firstorder conditions with at least 10 -fold excess of $\mathrm{NH}_{2} \mathrm{Cl}$ in a $\mathrm{pH}$ range of $6.1-8.9$ and a temperature range of $6-33^{\circ} \mathrm{C}$. Experiments were conducted in $250 \mathrm{~mL}$ brown glass reactors to exclude potential light influence. To restrain MC from hydrolysis, the reaction solution of MC $(10 \mu \mathrm{M})$ was freshly prepared by spiking a desired volume of its stock solution into $100 \mathrm{~mL}$ of ultrapure water buffered with $10 \mathrm{mM} \mathrm{KH}_{2} \mathrm{PO}_{4}$. Note that the presence of methanol, at a level of below $1.0 \%(\mathrm{v} / \mathrm{v})$, has negligible impact on the reaction of $\mathrm{NH}_{2} \mathrm{Cl}$ towards an organic compound (Greyshock and Vikesland, 2006). Our preliminary experiment had also confirmed that $0.8 \%(\mathrm{v} / \mathrm{v})$ methanol exerted insignificant influence on MC degradation by $\mathrm{NH}_{2} \mathrm{Cl}$ in this study.

After adjusting the reaction solution $\mathrm{pH}$, a desired volume of $\mathrm{NH}_{2} \mathrm{Cl}$ stock solution was spiked to initiate the reaction. Samples were withdrawn at pre-selected time intervals, and the residual oxidant was immediately quenched with preadded $\mathrm{Na}_{2} \mathrm{SO}_{3}$ solution. Each sample was extracted with $2 \mathrm{~mL}$ of MTBE, and then analyzed with gas chromatography/ mass spectrometry (GC/MS, 7890 GC and 5975 MSD, Agilent) to determine the residual MC concentration. The degradation experiments were conducted in duplicate, and the relative standard deviations of all measurement data were determined to be below $5 \%$. 


\subsection{Analytical methods}

MC was analyzed with GC/MS equipped with an HP-5 capillary column $(30 \mathrm{~m} \times 0.25 \mathrm{~mm}, 0.25 \mu \mathrm{m})$ in kinetic experiments. The injection temperature was $280^{\circ} \mathrm{C}$, and the column temperature was programmed as follows: started at $90^{\circ} \mathrm{C}$ and held for $1 \mathrm{~min}$, ramped at $20^{\circ} \mathrm{C} \mathrm{min} \mathrm{min}^{-1}$ to $280^{\circ} \mathrm{C}$ and then held for $2 \mathrm{~min}$. High purity helium gas was used as the carrier gas at a flow rate of $1 \mathrm{~mL} \mathrm{~min}^{-1}$. The MS quadrupole and source temperatures were set at 150 and $230{ }^{\circ} \mathrm{C}$, respectively. The quantification and confirmation ions for $\mathrm{MC}$ adopted in the selective ion mode (SIM) were 168 and 153, respectively. $\mathrm{NH}_{2} \mathrm{Cl}$ was measured with Hach Indophenol Method 10172 on a UV-Vis spectrophotometer (DR5000, Hach). Solution pH and temperature were measured simultaneously by using a Mettler Toledo Delta 320 pH meter.

Byproducts formed during $\mathrm{MC}$ degradation by $\mathrm{NH}_{2} \mathrm{Cl}$ were identified with GC/MS and HPLC/PDA/MS. MCXP and MCNP were identified with GC/MS as follows: 1 ) transfer the sample to a glass tube of cuspate bottom; 2) evaporate it under vacuum until dryness in a water bath of $40^{\circ} \mathrm{C}$; 3) add $100 \mu \mathrm{L}$ BSTFA and $100 \mu \mathrm{L}$ pyridine to the dry residue; 4) vortex for $20 \mathrm{~s}$ with the tube capped and heat in a water bath of $60^{\circ} \mathrm{C}$ for $20 \mathrm{~min}$; 5) cool the mixture down to room temperature, and blow off the residual BSTFA and pyridine under a gentle stream of nitrogen gas; and 6) dissolve the resulting derivatives in $1 \mathrm{~mL}$ acetone and analyze with GC/MS.

MCX was identified with HPLC/MS by comparing its retention time and MS spectrum with those of an authentic standard. An Atlantis C18 column $(150 \mathrm{~mm} \times 2.1 \mathrm{~mm}, 3 \mu \mathrm{m})$ was used for organic separation at a constant temperature of $40{ }^{\circ} \mathrm{C}$ and an acetonitrile/water eluent flow rate of $0.2 \mathrm{~mL} \mathrm{~min}^{-1}$. The eluent gradient consisted of 3 min elution with $20 \%$ acetonitrile, linearly ramped to $60 \%$ acetonitrile over $5 \mathrm{~min}$ and held for $4 \mathrm{~min}$, and then decreased to $20 \%$ acetonitrile over $3 \mathrm{~min}$ and held for $10 \mathrm{~min}$. The MS system was operated in the positive ionization mode with an electrospray ionization source under the following conditions: capillary voltage $3.5 \mathrm{kV}$, cone voltage $20 \mathrm{~V}$, source temperature $120^{\circ} \mathrm{C}$, and desolvation temperature $300^{\circ} \mathrm{C}$. High purity nitrogen gas was used as both cone and desolvation gases at a flow rate of 50 and $300 \mathrm{~L} \mathrm{~h}^{-1}$, respectively.

After being identified, the three major byproducts (MCXP, MCNP and MCX) together with the parent compound (MC) were further quantified by HPLC/PDA in a wavelength range from 209 to $211 \mathrm{~nm}$ under the separation conditions mentioned above.

\section{Results and discussion}

\subsection{Determination of reaction order}

Previous studies have shown that the reaction between $\mathrm{NH}_{2} \mathrm{Cl}$ and an organic compound is usually of first-order with respect to the organic compound (Greyshock and Vikesland, 2006; Chamberlain and Adams, 2006; Rodríguez et al., 2007). Fig. 1a shows the pseudo-first-order kinetic simulation (Eq. (1)) for $\mathrm{MC}$ degradation at $\mathrm{pH} 7.5$ with various initial $\mathrm{NH}_{2} \mathrm{Cl}$
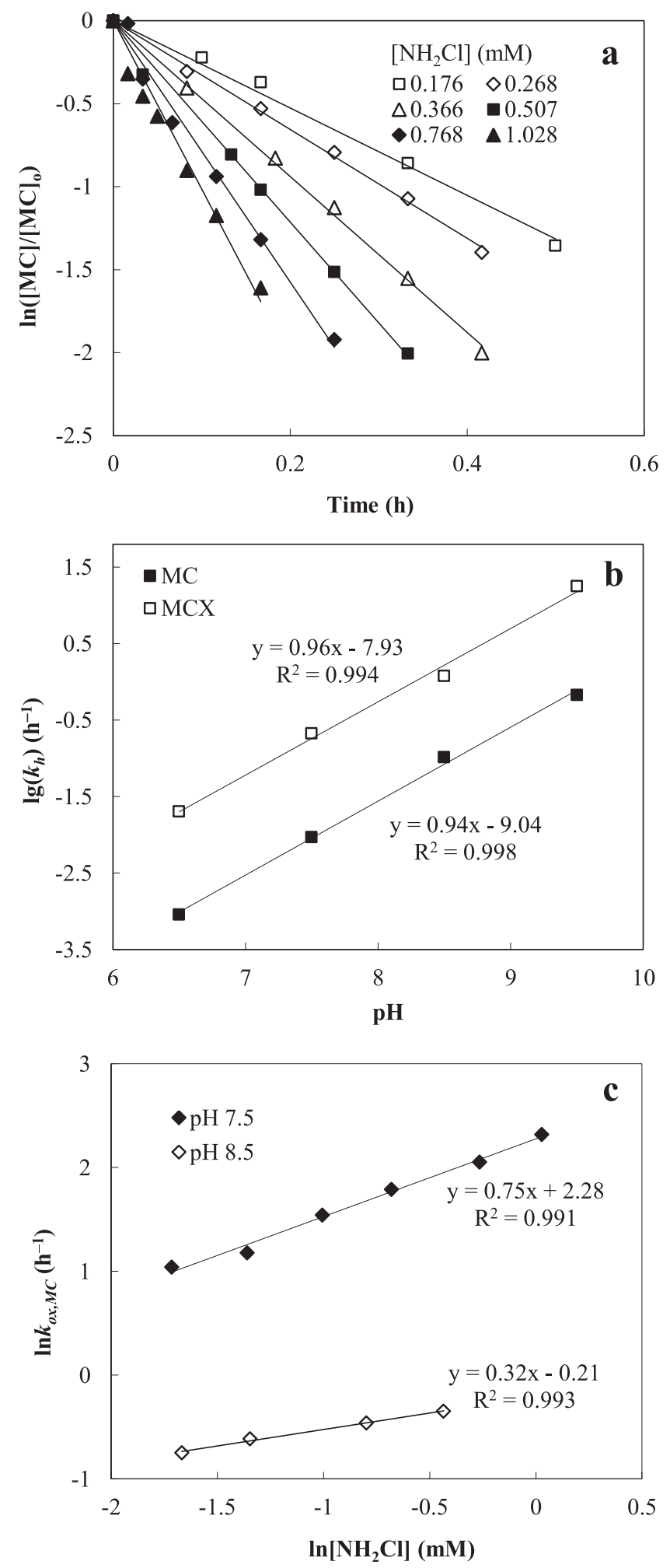

Fig. 1 - Determination of the reaction order for MC degradation by $\mathrm{NH}_{2} \mathrm{Cl}$ : (a) plot of $\ln \left([\mathrm{MC}] /[\mathrm{MC}]_{0}\right)$ vs. reaction time at pH 7.5; (b) plot of lgk $\mathrm{gs.} \mathrm{pH} \mathrm{for} \mathrm{MC} \mathrm{and} \mathrm{MCX;} \mathrm{and} \mathrm{(c)}$ plot of $\ln k_{o x, M C}$ vs. $\ln \left[\mathrm{NH}_{2} \mathrm{Cl}\right]$ at $\mathrm{pHs} 7.5$ and 8.5. Experimental conditions: $[\mathrm{MC}]_{\mathrm{o}}=[\mathrm{MCX}]_{\mathrm{o}}=10 \mu \mathrm{M}$, $\mathrm{T}=26 \pm 2{ }^{\circ} \mathrm{C}$. 

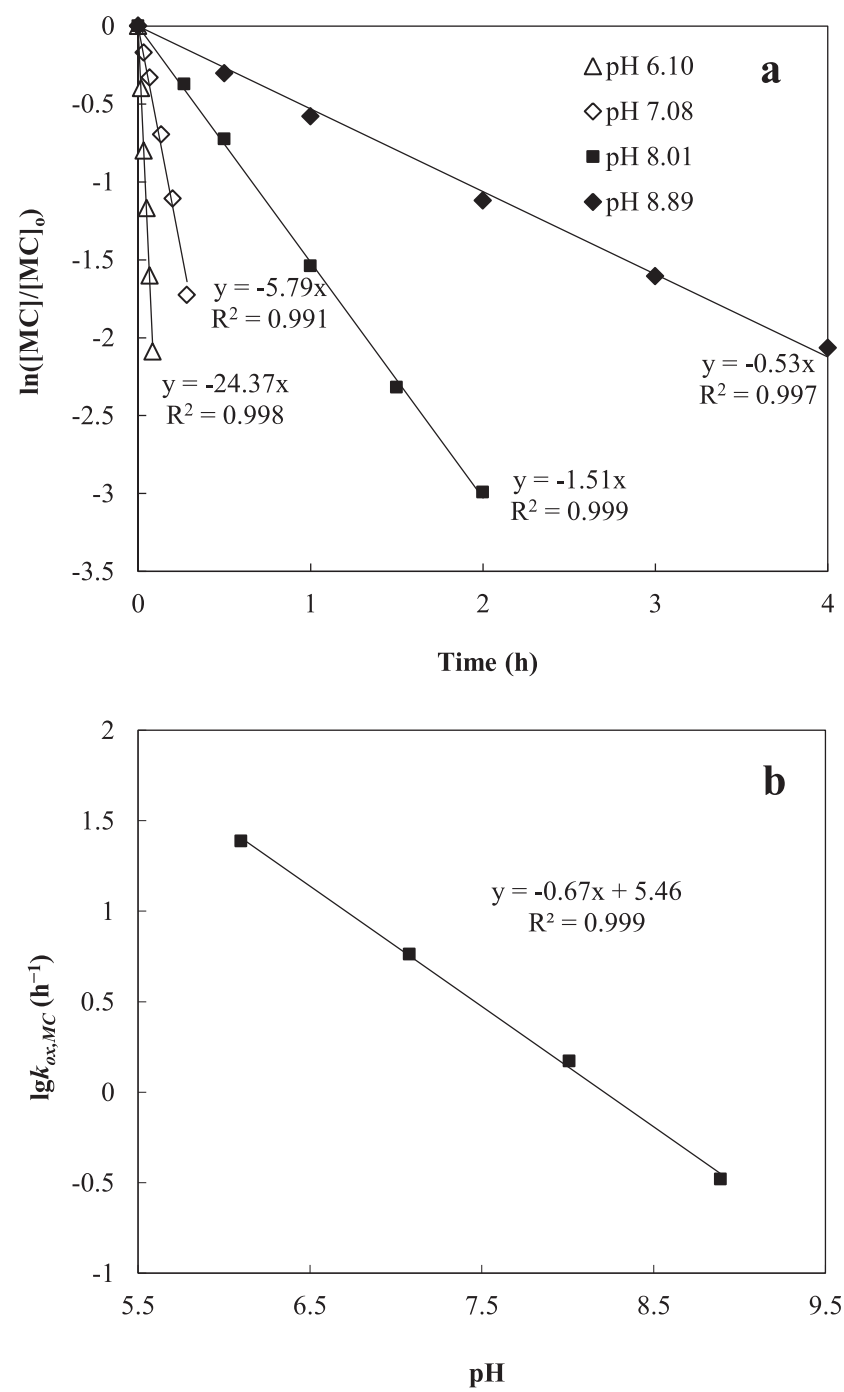

Fig. 2 - (a) Plot of $\ln \left([\mathrm{MC}] /[\mathrm{MC}]_{0}\right)$ vs. reaction time at different pHs; and (b) plot of lgk ${ }_{\mathrm{ox}, \mathrm{MC}}$ vs. pH. Experimental conditions: $[\mathrm{MC}]_{\mathrm{o}}=10 \mu \mathrm{M},\left[\mathrm{NH}_{2} \mathrm{Cl}\right]_{\mathrm{o}}=0.218 \mathrm{mM}$,

$\mathrm{T}=26 \pm 2{ }^{\circ} \mathrm{C}$.

concentrations. The good linearity of the fitting curves indicates a first-order reaction in MC.

$\ln \left([\mathrm{MC}] /[\mathrm{MC}]_{\mathrm{o}}\right)=-k_{\mathrm{obs}} \mathrm{t}$

where $k_{\text {obs }}$ represents the observed pseudo-first-order rate constant of MC degradation.
It is known that MC can hydrolyze to MCP in aqueous solution (UNFAO and WHO, 1999; APVMA, 2005). Hence, the $k_{\text {obs }}$ was ascribed to both hydrolysis and oxidation reactions in the presence of $\mathrm{NH}_{2} \mathrm{Cl}$. To attain the oxidation rate of $\mathrm{MC}\left(k_{\mathrm{ox}, \mathrm{MC}}\right)$ by $\mathrm{NH}_{2} \mathrm{Cl}$, the hydrolysis rate $\left(k_{h, \mathrm{MC}}\right)$ was determined experimentally under various $\mathrm{pH}$ conditions. Fig. $1 \mathrm{~b}$ shows that the $\lg \left(k_{h, \mathrm{MC}}\right)$ increased linearly with the solution $\mathrm{pH}$.

The oxidation rate of $\mathrm{MC}$ by $\mathrm{NH}_{2} \mathrm{Cl}$ can be expressed as follows:

$\mathrm{d}[\mathrm{MC}] / \mathrm{dt}=-k^{\prime \prime}\left[\mathrm{NH}_{2} \mathrm{Cl}\right]^{m}[\mathrm{MC}]$

where $k^{\prime \prime}$ is the specific rate constant and $m$ is the reaction order with respect to $\mathrm{NH}_{2} \mathrm{Cl}$. When $\mathrm{NH}_{2} \mathrm{Cl}$ is applied in large excess, Eq. (2) can be rearranged to:

$\ln k_{\mathrm{ox}, \mathrm{MC}}=m \ln \left[\mathrm{NH}_{2} \mathrm{Cl}\right]+\ln k^{\prime \prime}$

Fig. 1c shows the plot of $\ln k_{\mathrm{ox}, \mathrm{MC}}$ vs. $\ln \left[\mathrm{NH}_{2} \mathrm{Cl}\right]$ at $\mathrm{pHs} 7.5$ and 8.5. At pH 7.5, $m$ was equal to 0.75 (the slope) and $k^{\prime \prime}$ was calculated from the intercept to be $0.48 \mathrm{M}^{-0.75} \mathrm{~s}^{-1}$. At $\mathrm{pH} 8.5$, the values of $m$ and $k^{\prime \prime}$ significantly decreased to 0.32 and $2.02 \times 10^{-3} \mathrm{M}^{-0.32} \mathrm{~s}^{-1}$, respectively. It is seen that the reaction order with respect to $\mathrm{NH}_{2} \mathrm{Cl}$ was lower than 1 and strongly $\mathrm{pH}$ dependent. Similar results were reported for the reactions between two other carbamates (i.e., methomyl and aldicarb) and chlorine (Mason et al., 1990). Since pH was a critical influential factor, its effect on MC degradation was further examined.

\subsection{Effect of $p H$}

The $\mathrm{pH}$ dependence of $\mathrm{MC}$ degradation by $\mathrm{NH}_{2} \mathrm{Cl}$ is manifested in Fig. 2a. Results indicate that the observed degradation rate of MC ( $k_{\text {obs }}$ ) decreased from $24.37 \mathrm{~h}^{-1}$ at $\mathrm{pH} 6.10$ to $0.53 \mathrm{~h}^{-1}$ at $\mathrm{pH}$ 8.89. After subtracting the hydrolysis rate, the $l g k_{\mathrm{ox}, \mathrm{MC}}$ exhibited a linear decrease with an increase in the solution $\mathrm{pH}$ (Fig. 2b).

The reaction between $\mathrm{MC}$ and $\mathrm{NH}_{2} \mathrm{Cl}$ could be promoted by hydrogen ion $\left(\mathrm{H}^{+}\right)$, since $\mathrm{NH}_{2} \mathrm{Cl}$ would neither protonate nor deprotonate in the studied $\mathrm{pH}$ range $\left(\mathrm{pK}_{\mathrm{a}}=-1.45\right)$ (Gray et al., 1978) and MC would not ionize in aqueous solution (UNFAO and WHO, 1999). The possible mechanism for MC oxidation, according to Peskin and Winterbourn (2001), is illustrated in Scheme 1. Hydrogen ion could catalytically promote the transfer of chlorine from $\mathrm{NH}_{2} \mathrm{Cl}$ to the sulfur of $\mathrm{MC}$, yielding a chlorosulfonium cationic intermediate. Afterward, sulfoxide was formed as a result of the hydrolysis of this intermediate.

In addition, $\mathrm{NH}_{2} \mathrm{Cl}$ would hydrolyze weakly to produce $\mathrm{HOCl}$ that has a much higher reactivity than $\mathrm{NH}_{2} \mathrm{Cl}$<smiles>CSc1c(C)cc(OC(=O)[O-])cc1C</smiles>

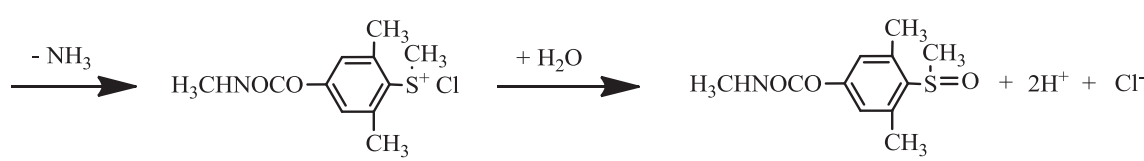

Scheme 1 - Acid-catalyzed MC degradation by $\mathrm{NH}_{2} \mathrm{Cl}$. 
(Chamberlain and Adams, 2006; Qiang et al., 2006; Rodríguez et al., 2007). The degree of $\mathrm{NH}_{2} \mathrm{Cl}$ hydrolysis increases with a decrease in the solution $\mathrm{pH}$ (Morris and Issac, 1983). The secondary $\mathrm{HOCl}$ may also contribute to the MC degradation. To clarify the role of $\mathrm{HOCl}$ in $\mathrm{MC}$ degradation, the effect of $\mathrm{Cl}_{2}: \mathrm{N}$ ratio was further examined.

\subsection{Effect of $\mathrm{Cl}_{2}: \mathrm{N}$ ratio}

In the $\mathrm{pH}$ range of $6.5-8.5$, which is typical for drinking water treatment, $\mathrm{NH}_{2} \mathrm{Cl}$ is predominantly produced at a $\mathrm{Cl}_{2}: \mathrm{N}$ ratio $\leq 5: 1$ (by weight); otherwise, breakpoint chlorination will occur which reduces the residual chlorine. For chloramination, water utilities generally apply a $\mathrm{Cl}_{2}: \mathrm{N}$ weight ratio between 3 and 5 (i.e., molar ratio of $0.6-1.0$ ) (USEPA, 1999). In the chloramination process, the hydrolysis of $\mathrm{NH}_{2} \mathrm{Cl}$ will yield $\mathrm{HOCl}$ (Eq. (4)). Due to its high oxidation potential, $\mathrm{HOCl}$ cannot be neglected even though at a very low concentration. Therefore, $\mathrm{MC}$ degradation may be attributed to both the direct reaction with $\mathrm{NH}_{2} \mathrm{Cl}$ and the simultaneous indirect reaction with $\mathrm{HOCl}$.

$\mathrm{NH}_{2} \mathrm{Cl}+\mathrm{H}_{2} \mathrm{O} \rightleftharpoons \mathrm{HOCl}+\mathrm{NH}_{3}$

To examine the contribution of $\mathrm{HOCl}$ to $\mathrm{MC}$ degradation, experiments were conducted at various molar ratios of $\mathrm{Cl}_{2}: \mathrm{N}$ (from 0.79 to 0.01 ) at $\mathrm{pH}$ 7.5. Table 1 indicates that the observed degradation rate of $\mathrm{MC}\left(k_{\text {obs }}\right)$ first decreased with a decreasing $\mathrm{Cl}_{2}: \mathrm{N}$ ratio from 0.79 to 0.35 , and then approached nearly constant at molar ratios no more than 0.05 . It is inferred that MC was also oxidized by $\mathrm{HOCl}$ besides $\mathrm{NH}_{2} \mathrm{Cl}$, and a higher $\mathrm{Cl}_{2}: \mathrm{N}$ ratio caused a more significant contribution of $\mathrm{HOCl}$ to MC degradation. This result is similar to the degradation of triclosan by $\mathrm{NH}_{2} \mathrm{Cl}$ (Greyshock and Vikesland, 2006).

\subsection{Effect of temperature}

The effect of temperature on MC degradation was studied at $\mathrm{pH} 7.5$ from 6 to $33^{\circ} \mathrm{C}$, which represents a typical temperature range for drinking water treatment. The results indicate that the $k_{\text {obs }}$ increased rapidly with an increase in temperature at a constant $\mathrm{pH}$ (Fig. S1), as expressed by the Arrhenius equation:

$k_{\mathrm{obs}}=5.37 \times 10^{6} \exp (-4083.7 / \mathrm{T})$

The apparent activation energy was calculated to be $34 \mathrm{~kJ} \mathrm{~mol}^{-1}$, which is considerably lower than $75 \mathrm{~kJ} \mathrm{~mol}^{-1}$ for MC reaction with $\mathrm{ClO}_{2}$ (Tian et al., 2010). According to this value, a $10^{\circ} \mathrm{C}$ temperature increase will raise the reaction rate by 1.6 times.

Table 1 - The observed pseudo-first-order rate constant ( $k_{\text {obs }}$ ) of $\mathrm{MC}$ degradation by $\mathrm{NH}_{2} \mathrm{Cl}$ at various molar ratios of $\mathrm{Cl}_{2}: \mathrm{N}$ ([MC]。 $\left.=10 \mu \mathrm{M}, \mathrm{pH}=7.5, \mathrm{~T}=25 \pm 2^{\circ} \mathrm{C}\right)$.

\begin{tabular}{lcc}
$\mathrm{Cl}_{2}: \mathrm{N}$ & {$\left[\mathrm{NH}_{2} \mathrm{Cl}\right](\mathrm{mM})$} & $k_{\text {obs }}\left(\mathrm{h}^{-1}\right)$ \\
\hline 0.79 & 0.507 & 6.065 \\
0.65 & 0.430 & 4.449 \\
0.51 & 0.401 & 3.928 \\
0.35 & 0.408 & 2.669 \\
0.05 & 0.451 & 2.024 \\
0.01 & 0.514 & 2.074 \\
\hline
\end{tabular}

\subsection{Proposed degradation pathways}

It was reported that MC could either be degraded to MCX or lose its carbamate group via hydrolysis to yield MCP in aqueous solution (UNFAO and WHO, 1999; APVMA, 2005). Since the solution $\mathrm{pH}$ greatly impacted MC degradation by $\mathrm{NH}_{2} \mathrm{Cl}$ as mentioned above, it could also alter the degradation pathways and produce different byproducts.

The formation of byproducts along with MC degradation by $\mathrm{NH}_{2} \mathrm{Cl}$ was studied at $\mathrm{pH}$ values of $6.5,7.5$ and 8.5 , as shown in Fig. 3. Results indicate that at $\mathrm{pH} 6.5$, MC was

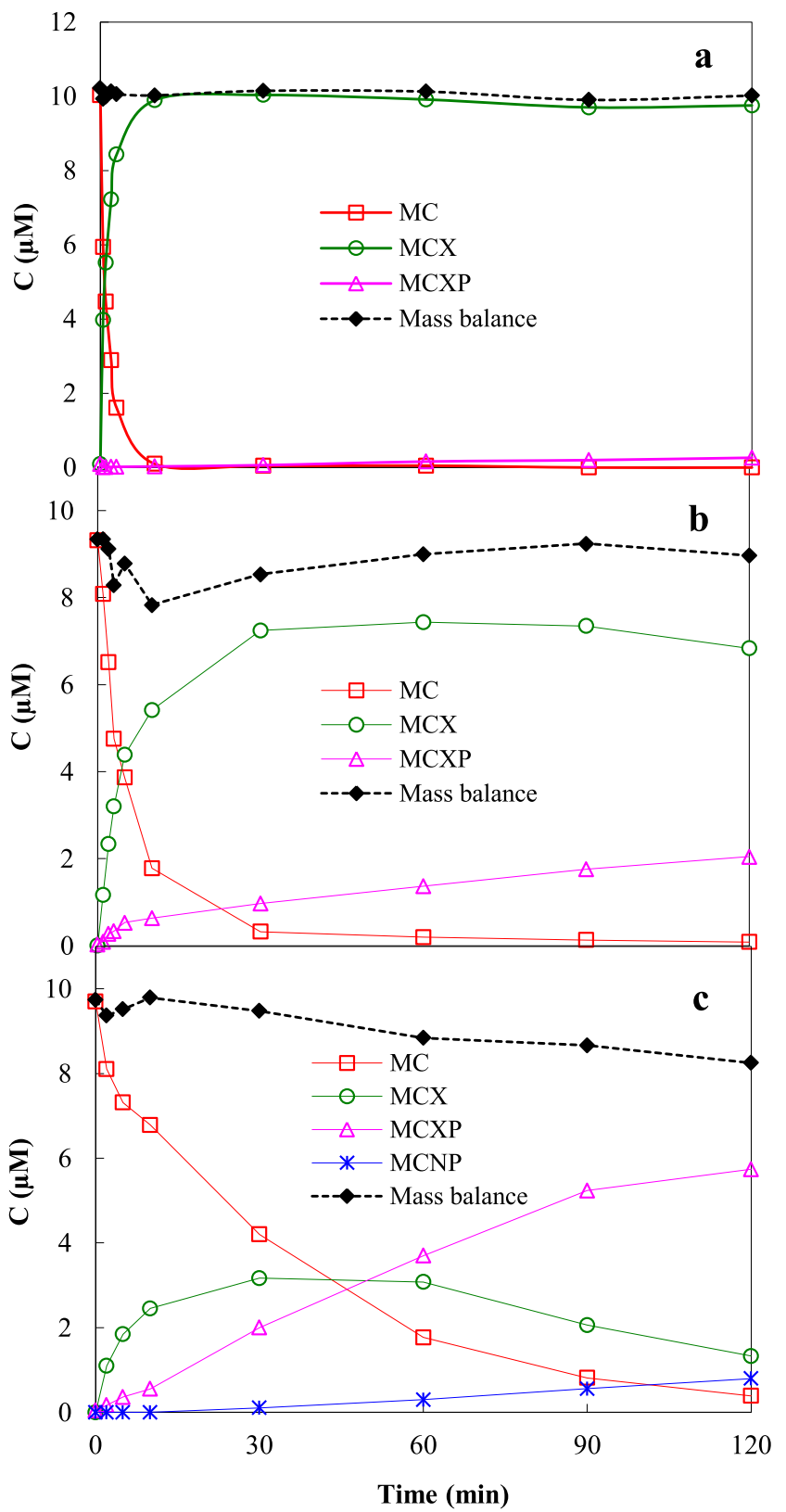

Fig. 3 - Byproducts formation along with MC degradation by $\mathrm{NH}_{2} \mathrm{Cl}$ at: (a) $\mathrm{pH}$ 6.5; (b) $\mathrm{pH} 7.5$; and (c) pH 8.5.

Experimental conditions: $[\mathrm{MC}]_{\circ}=9.3-10 \mu \mathrm{M}$; $\left[\mathrm{NH}_{2} \mathrm{Cl}\right]_{\mathrm{o}}=1.108 \mathrm{mM}, \mathrm{T}=26 \pm 2{ }^{\circ} \mathrm{C}$; mass balance was based on benzene ring; the relative standard deviations of all measurement data were below $10 \%$. 
oxidized quickly to MCX within $10 \mathrm{~min}$, which was a major and fairly stable byproduct. A small amount of MCXP was also detected due to the further hydrolysis of MCX, which only accounted for about 3\% of the initial MC concentration at the end of the reaction (i.e., $2 \mathrm{~h}$ ). The good mass balance on the basis of benzene ring (i.e., including MC, MCX and MCXP) throughout the reaction course indicates that all major byproducts were identified at this $\mathrm{pH}$. At $\mathrm{pH} 7.5$, the MC degradation was retarded to some extent, but MCX was still a major byproduct; more MCXP was generated due to an enhanced hydrolysis of MCX at this elevated $\mathrm{pH}$, which accounted for $22 \%$ of the initial MC concentration at $2 \mathrm{~h}$. At $\mathrm{pH} 8.5$, the concentration of MCX decreased greatly because of its rapid hydrolysis to MCXP under a basic condition, which accounted for $59 \%$ of the initial MC concentration at $2 \mathrm{~h}$. Moreover, MCNP emerged as a new byproduct and accumulated with reaction time, implying that $\mathrm{NH}_{2} \mathrm{Cl}$ could more easily oxidize MCXP than MCX. The mass balance based on benzene ring showed a deficiency of ca. 15\% at the end of the reaction, most probably due to some unidentified byproducts. Because MCX is more toxic than MC and other identified byproducts (i.e., MCXP and MCNP), the MC solution would have a less toxicity after treatment by $\mathrm{NH}_{2} \mathrm{Cl}$ at a higher $\mathrm{pH}$ (Fig. S2).

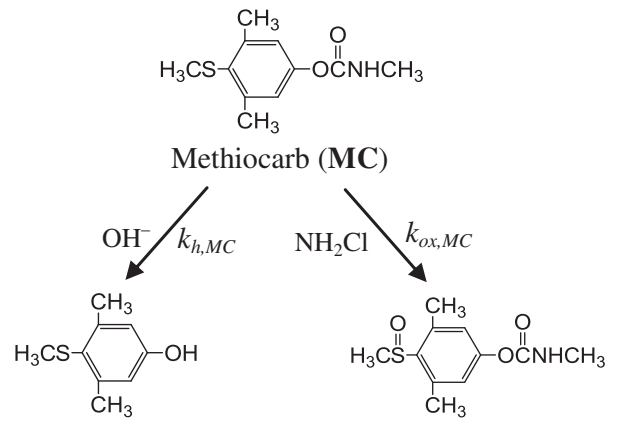

Methiocarb phenol (MCP)<smiles>Cc1cc(O)cc(C)c1S(=O)(=O)CCCCCCO</smiles>

Methiocarb sulfoxide phenol (MCXP)

$$
k_{O x, M C X P}
$$

Methiocarb sulfone phenol (MCNP)

$$
\mathrm{NH}_{2} \mathrm{Cl} \downarrow k_{o x, M C N P}
$$

Further oxidation byproducts

Fig. 4 - Proposed pathways of MC degradation in the presence of $\mathrm{NH}_{2} \mathrm{Cl}$.
Based on the identified byproducts and their concentrations evolution over the reaction course, the degradation pathways of $\mathrm{MC}$ in the presence of $\mathrm{NH}_{2} \mathrm{Cl}$ were proposed (Fig. 4). Although $\mathrm{NH}_{2} \mathrm{Cl}$ oxidation played a primary role in $\mathrm{MC}$ degradation, hydrolysis reactions occurred simultaneously. The initial attack of $\mathrm{NH}_{2} \mathrm{Cl}$ on the sulfur of $\mathrm{MC}$ produced a major oxidation byproduct, MCX, which could hydrolyze easily to MCXP in aqueous solution. In the meanwhile, the hydrolysis of MC led to the formation of MCP, whose continuous oxidation by $\mathrm{NH}_{2} \mathrm{Cl}$ yielded MCXP. The oxidation rate of MCP by $\mathrm{NH}_{2} \mathrm{Cl}\left(k_{\mathrm{Ox}, \mathrm{MCP}}\right)$ was experimentally determined to be $7.23 \mathrm{~h}^{-1}$ at $\mathrm{pH} 8.5$ (Fig. 5a), which is much higher than its formation rate through the hydrolysis of $\mathrm{MC}\left(0.10 \mathrm{~h}^{-1}\right.$, experimentally determined, Table 2) at the same $\mathrm{pH}$. As a consequence, MCP could not be detected in the reaction
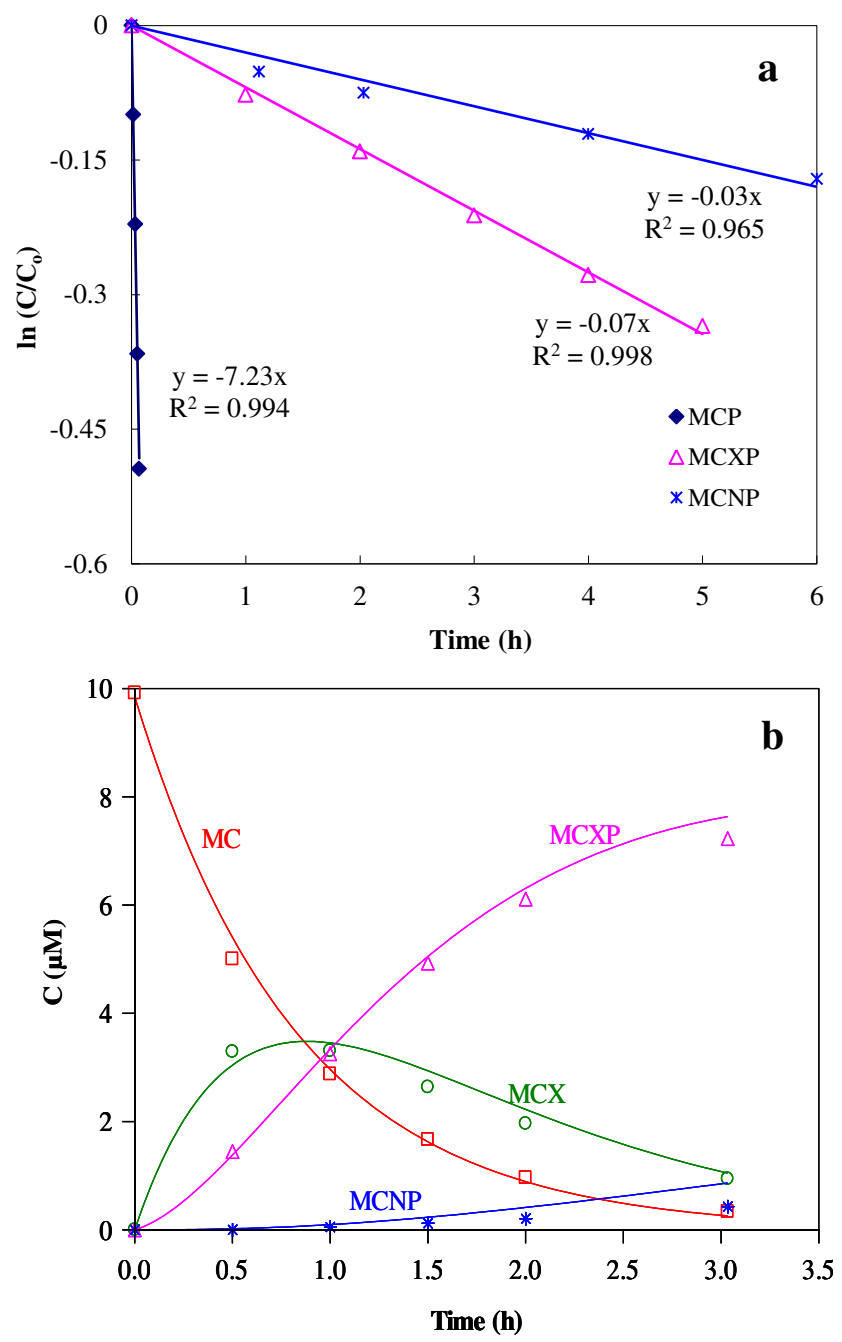

Fig. 5 - (a) The degradation kinetics of MCP, MCXP and MCNP by $\mathrm{NH}_{2} \mathrm{Cl}\left([\mathrm{MCP}]_{\mathrm{o}}=[\mathrm{MCXP}]_{\mathrm{o}}=[\mathrm{MCNP}]_{\mathrm{o}}=10 \mu \mathrm{M}\right)$; and (b) the model simulations of byproducts formation along with $\mathrm{MC}$ degradation by $\mathrm{NH}_{2} \mathrm{Cl}$ ([MC]o $\left.=10 \mu \mathrm{M}\right)$. Experimental conditions: $\left[\mathrm{NH}_{2} \mathrm{Cl}\right]_{\mathrm{o}}=0.486 \mathrm{mM}, \mathrm{pH}=8.5$, $\mathrm{T}=26 \pm 2{ }^{\circ} \mathrm{C}$; the symbols represent measurement data and the curves represent model-fitting; the relative standard deviations of all measurement data were below $10 \%$. 
Table 2 - Comparison of experimental and modeled rate constants of related reactions for MC degradation in the presence of $\mathrm{NH}_{2} \mathrm{Cl}\left(\mathrm{pH}=8.5, \mathrm{~T}=26 \pm 2^{\circ} \mathrm{C}\right)$.

No.

Reactions
Rate constants $\left(\mathrm{h}^{-1}\right)$

Experimental data

$k_{\mathrm{ox}, \mathrm{MC}}=1.07 \pm 0.03$

$k_{h, \mathrm{MC}}=0.10 \pm 0.01$

$k_{h, \mathrm{MCx}}=1.19 \pm 0.08$

$k_{\mathrm{OX}, \mathrm{MCP}}=7.23 \pm 0.02$

$k_{\mathrm{ox}, \mathrm{MCXP}}=0.07 \pm 0.00$

$k_{\mathrm{ox}, \mathrm{MCNP}}=0.03 \pm 0.01$

$\mathrm{MCXP}+\mathrm{NH}_{2} \mathrm{Cl}+\mathrm{H}_{2} \mathrm{O} \underset{k_{\text {ox:MCNP }}}{\stackrel{k_{\text {OCXP }}}{\longrightarrow}} \mathrm{MCNP}+\mathrm{NH}_{4}^{+}+\mathrm{Cl}^{-}$

$\mathrm{MCNP}+\mathrm{NH}_{2} \mathrm{Cl}+\mathrm{H}_{2} \mathrm{O} \stackrel{k_{\mathrm{Ox} M C N P}}{\rightarrow}$ other byproducts

6

Mean \pm standard deviation $(n=2)$.

solution. A further attack on the $-(\mathrm{S}=\mathrm{O})$ - moiety of MCXP by $\mathrm{NH}_{2} \mathrm{Cl}$ generated MCNP, and the reaction rate constant was measured to be $0.07 \mathrm{~h}^{-1}$ at pH 8.5 (Fig. 5a). MCNP was also reactive towards $\mathrm{NH}_{2} \mathrm{Cl}$, although with a notably lower rate constant $\left(0.03 \mathrm{~h}^{-1}\right.$, Fig. $\left.5 \mathrm{a}\right)$. It is seen that the reaction rates of the phenolic byproducts towards $\mathrm{NH}_{2} \mathrm{Cl}$ decreased successively from MCP, MCXP, to MCNP. The proposed pathways suggest that a basic condition should favor the degradation of MC by $\mathrm{NH}_{2} \mathrm{Cl}$ because MCXP and MCNP are much less toxic than MC and MCX (Fig. S2).

To verify the proposed pathways of MC degradation in the presence of $\mathrm{NH}_{2} \mathrm{Cl}$, Scientist ${ }^{\circledR}$ software (Micromath, Salt Lake, UT) was utilized to simulate the formation of byproducts along with the degradation of $\mathrm{MC}$ at $\mathrm{pH} 8.5$ based upon the related reactions as listed in Table 2 . Considering the fact that MCP was formed but could not be detected during the reaction course, in the model simulation process, the two-step pathways from MC to MCP (via hydrolysis) and further to MCXP (via oxidation) were simplified as one transformation step, i.e., directly from MC to MCXP with a rate constant of $k_{h, \mathrm{MC}}$. This simplification is reasonable because the hydrolysis of $\mathrm{MC}$ to $\operatorname{MCP}\left(k_{h, \mathrm{MC}}=0.10 \mathrm{~h}^{-1}\right)$ was the rate-limiting step in comparison to the oxidation of MCP to $\operatorname{MCXP}\left(k_{\mathrm{Ox}, \mathrm{MCP}}=7.23 \mathrm{~h}^{-1}\right)$. The simulated curves are presented in Fig. $5 b$, and the simulated rate constants are given in Table 2 . The good agreement between model predictions and experimental measurements well confirms the rationality of the proposed pathways for MC degradation in the presence of $\mathrm{NH}_{2} \mathrm{Cl}$.

\section{Conclusions}

This work investigated the kinetics and pathways of MC degradation by $\mathrm{NH}_{2} \mathrm{Cl}$ under typical water treatment conditions. Based on the experimental results, the following conclusions can be drawn:

- The reaction between $\mathrm{MC}$ and $\mathrm{NH}_{2} \mathrm{Cl}$ was of first-order in $\mathrm{MC}$ and varied orders in $\mathrm{NH}_{2} \mathrm{Cl}$. The observed pseudo-firstorder rate constant of $\mathrm{MC}$ degradation was strongly $\mathrm{pH}$ dependent, which quickly decreased from 24.37 to $0.53 \mathrm{~h}^{-1}$ as the solution $\mathrm{pH}$ increased from 6.10 to 8.89 .

- MC degradation was attributed to both the direct reaction with $\mathrm{NH}_{2} \mathrm{Cl}$ and the indirect reaction with $\mathrm{HOCl}$ produced from $\mathrm{NH}_{2} \mathrm{Cl}$ hydrolysis. The apparent activation energy for $\mathrm{MC}$ reacting with $\mathrm{NH}_{2} \mathrm{Cl}$ was determined as $34 \mathrm{~kJ} \mathrm{~mol}^{-1}$.
- MCX and MCXP were two major byproducts identified in MC degradation by $\mathrm{NH}_{2} \mathrm{Cl}$ at pHs 6.5 and 7.5, while MCNP emerged as a new byproduct at $\mathrm{pH}$ 8.5. Although $\mathrm{NH}_{2} \mathrm{Cl}$ oxidation played a primary role in $\mathrm{MC}$ degradation, hydrolysis reactions occurred simultaneously, especially under basic conditions.

- The proposed pathways of MC degradation in the presence of $\mathrm{NH}_{2} \mathrm{Cl}$ were substantiated through kinetic model simulations.

\section{Acknowledgments}

This work was financially supported by the National Natural Science Foundation $(51290281,51221892)$ and the Ministry of Science and Technology (2012BAJ25B04, 2012ZX07404-004) of China.

\section{Appendix A. Supplementary data}

Supplementary data related to this article can be found at http://dx.doi.org/10.1016/j.watres.2013.12.011.

\section{R E F E R E N C E S}

Altinok, I., Capkin, E., Karahan, S., Boran, M., 2006. Effects of water quality and fish size on toxicity of methiocarb, a carbamate pesticide, to rainbow trout. Environ. Toxicol. Pharmacol. 22 (1), 20-26.

APVMA, 2005. Methiocarb Preliminary Review Findings Report, Part D, Environment, vol. 2. Australian Pesticides and Veterinary Medicines Authority, Canberra, Australian, pp. 307-360.

Barcelo, D., Chiron, S., Fernandez-Alba, A., Valverde, A., Alpendurada, M.F., 1996. Monitoring pesticides and metabolites in surface water and groundwater in Spain. In: Meyer, M.T., Thurman, E.M. (Eds.), Herbicide Metabolites in Surface Water and Groundwater, ACS Symposium Series 630. American Chemical Society, Washington, DC, pp. 237-253.

Chamberlain, E., Adams, C., 2006. Oxidation of sulfonamides, macrolides, and carbadox with free chlorine and monochloramine. Water Res. 40 (13), 2517-2526.

Choi, J., Valentine, R.L., 2002. Formation of Nnitrosodimethylamine (NDMA) from reaction of 
monochloramine: a new disinfection by-product. Water Res. 36 (4), 817-824.

Duirk, S.E., Gombert, B., Choi, J., Valentine, R.L., 2002. Monochloramine loss in the presence of humic acid. J. Environ. Monit. 4 (1), 85-89.

Garcia de Llasera, M.P., Bernal-Gonzalez, M., 2001. Presence of carbamate pesticides in environmental waters from the northwest of Mexico: determination by liquid chromatography. Water Res. 35 (8), 1933-1940.

Gitahi, S.M., Harper, D.M., Muchiri, S.M., Tole, M.P., Ng'ang'a, R.N., 2002. Organochlorine and organophosphorus pesticide concentrations in water, sediment, and selected organisms in Lake Naivasha (Kenya). Hydrobiologia 488 (1-3), 123-128.

Gray Jr., E.T., Margerum, D.W., Huffman, R.P., 1978. Chloramine equilibria and the kinetics of disproportionation in aqueous solution. In: Brinckman, F.E., Bellama, J.M. (Eds.),

Organometals and Organometalloids; Occurrence and Fate in the Environment, ACS Symposium Series 82. American Chemical Society, Washington, DC, pp. 264-277.

Greyshock, A.E., Vikesland, P.J., 2006. Triclosan reactivity in chloraminated waters. Environ. Sci. Technol. 40 (8), 2615-2622.

Heasley, V.L., Fisher, A.M., Herman, E.E., Jacobsen, F.E., Miller, E.W., Ramirez, A.M., Royer, N.R., Whisenand, J.M., Zoetewey, D.L., Shellhamer, D.F., 2004. Investigations of the reactions of monochloramine and dichloramine with selected phenols: examination of humic acid models and water contaminants. Environ. Sci. Technol. 38 (19), 5022-5029.

Keum, Y.S., Liu, K.H., Lee, Y.S., Lee, J.S., Chung, B.J., Kim, J.H., 2000. Gas chromatographic analysis of methiocarb and its metabolites in soil and rice. Chromatographia 52 (3-4), 237-241.

Marrs, T.C., 1998. Methiocarb. In: Joint Meeting of the FAO Panel of Experts on Pesticide Residues in Food and the Environment and the WHO Core Assessment Group, Rome, pp. 203-223.

Mason, Y.Z., Choshen, E., Rav-Acha, C., 1990. Carbamate insecticides: removal from water by chlorination and ozonation. Water Res. 24 (1), 11-21.

Morris, J.C., Issac, R.A., 1983. A critical review of kinetic and thermodynamic constants for the aqueous chlorine-ammonia system. In: Jolley, R.L., Bull, R.J., Davis, W.P., Katz, S., Roberts, M.H.J., Jacobs, V.A. (Eds.), Water Chlorination: Environmental Impact and Health Effects, vol. 4Ann Arbor Science, Ann Arbor, MI, pp. 49-62.

Ormad, M.P., Miguel, N., Claver, A., Matesanz, J.M., Ovelleiro, J.L., 2008. Pesticides removal in the process of drinking water production. Chemosphere 71 (1), 97-106.
Peskin, A.V., Winterbourn, C.C., 2001. Kinetics of the reactions of hypochlorous acid and amino acid chloramines with thiols, methionine, and ascorbate. Free Rad. Biol. Med. 30 (5), 572-579.

Qi, Y., Shang, C., Lo, I.M.C., 2004. Formation of haloacetic acids during monochloramination. Water Res. 38 (9), $2375-2383$.

Qiang, Z., Adams, C.D., 2004. Determination of monochloramine formation rate constants with stopped-flow spectrophotometry. Environ. Sci. Technol. 38 (5), 1435-1444.

Qiang, Z.M., Macauley, J.J., Mormile, M.R., Surampalli, R., Adams, C.D., 2006. Treatment of antibiotics and antibiotic resistant bacteria in swine wastewater with free chlorine. J. Agri. Food Chem. 54 (21), 8144-8154.

Rodríguez, E., Sordo, A., Metcalf, J.S., Acero, J.L., 2007. Kinetics of the oxidation of cylindrospermopsin and anatoxin-a with chlorine, monochloramine and permanganate. Water Res. 41 (9), 2048-2056.

Sandín-España, P., Magrans, J.O., García-Baudín, J.M., 2005. Study of clethodim degradation and by-product formation in chlorinated water by HPLC. Chromatographia 62 (3-4), 133-137.

Sinclair, C.J., Boxall, A.B.A., Parsons, S.A., Thomas, M.R., 2006. Prioritization of pesticide environmental transformation products in drinking water supplies. Environ. Sci. Technol. 40 (23), 7283-7289.

Squillace, P.J., Scott, J.C., Moran, M.J., Nolan, B.T., Kolpin, D.W., 2002. VOCs, pesticides, nitrate, and their mixtures in groundwater used for drinking water in the United States. Environ. Sci. Technol. 36 (9), 1923-1930.

Tian, F., Qiang, Z.M., Liu, C., Zhang, T., Dong, B.Z., 2010. Kinetics and mechanism for methiocarb degradation by chlorine dioxide in aqueous solution. Chemosphere 79 (6), 646-651.

UNFAO (Food and Agriculture Organization of the United Nations) and WHO (World Health Organization), 1999. Methiocarb (132). In: Joint Meeting of the FAO Panel of Experts on Pesticide Residues in Food and the Environment and the WHO Core Assessment Group, Rome, pp. 531-601.

USEPA, 1999. Chloramines. In: Alternative Disinfectants and Oxidants Guidance Manual. US Environmental Protection Agency, Office of Water, Washington, DC. US EPA815-R-99014.

Wu, J.G., Laird, D.A., 2003. Abiotic transformation of chlorpyrifos to chlorpyrifos oxon in chlorinated water. Environ. Toxicol. Chem. 22 (2), 261-264. 